\section{Serum cadmium levels in a sample of blood donors in the Western Amazon, Brazil, 2010-2011}

\author{
Níveis séricos de cádmio em uma amostra de \\ doadores de sangue na Amazônia Ocidental, \\ Brasil, 2010-2011
}

\author{
Niveles séricos de cadmio en una muestra de
donantes de sangre en la Amazonia occidental \\ Niveles séricos de cadmio en una muestra de
donantes de sangre en la Amazonia occidental, \\ Brasil, 2010-2011
}

\author{
André Ricardo Maia da Costa de Faro ${ }^{1}$ \\ Wagner de Jesus Pinto 1 \\ Aldo Pacheco Ferreira 2 \\ Fernando Barbosa Júnior 3 \\ Vanessa Cristina de Oliveira Souza 3 \\ Denys Eiti Fujimoto 1 \\ Rosalina Jorge Koifman 2 \\ Sérgio Koifman ${ }^{2}$
}

\title{
Resumo
}

\footnotetext{
1 Universidade Federal do Acre, Rio Branco, Brasil.

2 Escola Nacional de Saúde Pública Sergio Arouca, Fundação Oswaldo Cruz, Rio de Janeiro, Brasil. 3 Faculdade de Ciências Farmacêuticas de Ribeirão Preto, Universidade de São Paulo, Ribeirão Preto, Brasil.

Correspondence A. R. M. C. Faro

Universidade Federal do Acre. Campus Universitário BR 364, KM 04, Distrito Industrial, C. P. 500 (CCSD), Rio Branco, $A C$ 69920-900, Brasil. enfermeiromaia@hotmail.com
}

\begin{abstract}
A cross-sectional study was conducted to determine the distribution of serum cadmium $(\mathrm{Cd})$ levels in blood donors in Rio Branco, Acre State, Brazil. Blood samples were obtained from 922 volunteer blood donors from 18 to 65 years of age at the Hemoacre blood center in 2010-2011. Mean serum Cd was 0.37ug/L (95\%CI: 0.33-0.41). Increased serum Cd was associated with lower schooling; individuals with less than five years of schooling showed a mean Cd of $0.61 \mu \mathrm{g} / \mathrm{L}(95 \% \mathrm{CI}$ : 0.34-0.89), compared to $0.34 \mu \mathrm{g} / \mathrm{L}$ (95\%CI: 0.28 0.40) among those with more than nine years of schooling. Mean serum Cd was three times higher among smokers. Smoking showed a positive association with Cd level, with an OR of 12.36 (95\%CI: 7.70-19.84). Meanwhile, serum Cd was lower among individuals that regularly drank tea, as compared to non-tea drinkers. Serum Cd levels were mostly below the reference value (88.3\% of participants). Mean serum $\mathrm{Cd}$ in the current study indicates that in general the population studied here is not exposed to worrisome Cd levels.
\end{abstract}

Cadmium; Blood Donors; Cross-sectional Studies
Objetivou-se, por meio de estudo transversal, determinar a distribuição dos níveis séricos de cádmio (Cd) em doadores de sangue em Rio Branco, Acre, Brasil. O sangue foi obtido de 922 doadores voluntários entre 18 e 65 anos no $\mathrm{He}$ moacre, entre 2010-2011. A média da concen-

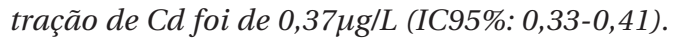
Houve tendência de aumento com a diminuição do nível de escolaridade; indivíduos com menos de cinco anos de estudo apresentaram média de 0,61 $\mu \mathrm{g} / \mathrm{L}$ (IC95\%: 0,34-0,89), enquanto aqueles com mais de nove anos de estudo obtiveram média de 0,34 $\mu$ g/L (IC95\%: 0,28-0,40). A média da concentração de Cd apresentou-se três vezes maior entre os fumantes. O tabagismo demonstrou associação positiva com OR 12,36 (IC95\%: 7,70-19,84). Já a concentração de Cd entre os indivíduos com hábitos de tomar chás apresentase menor quando comparada àqueles que não utilizam. Os níveis séricos de Cd foram, em sua maioria, abaixo do valor de referência (88,3\% dos participantes). As médias encontradas no presente estudo indicam que, no geral, a população estudada não está exposta a níveis preocupantes de exposição ao $\mathrm{Cd}$.

Cádmio; Doadores de Sangue; Estudos Transversais 


\section{Introduction}

Among the toxic pollutants, metals are naturally occurring elements. They are environmental contaminants that can be found in the water, soil, and foodstuffs. Thus, regardless of their safe use in industry and in consumer products, human exposure is inevitable 1,2,3,4. These elements are non-biodegradable and participate in the global life cycle, where water plays the main role. Metals come from a wide range of sources and are transported dynamically through the air, soil, and water and can remain in the environment for long periods 5,6 .

There are various manmade sources of cadmium (Cd). The main source is nickel-cadmium batteries, widely used in electric and electronic equipment and appliances. Other manmade sources of cadmium involve electric deposition of protective films around various objects, increasing their resistance to air corrosion 7 . Cadmium compound products are used as stabilizers in plastic products, in the composition of metallic paints, various types of metal alloys, and now more frequently as anticorrosive agents 8 . Approximately $75 \%$ of the Cd produced is used in manufacturing batteries, especially nickelcadmium and alkaline batteries, with a longer lifespan than traditional batteries 7 .

In addition, some $25 \%$ is used to manufacture antioxidant coating (electroplating) for iron objects and as a component in low melting point alloys (Wood's alloy, Lipowitz's alloy, and Newton's metal) for high-speed ball bearings in automobiles and aircraft 9 . Due to its low friction coefficient, cadmium is highly fatigue-resistant and is used for cushions, in various types of welds, and in control rods in nuclear fission 4,6 . It has been used recently as a moderating substance in atomic batteries and in semiconductors, besides use in the electronic industry for manufacturing TV screens, photovoltaic cells, electromagnetic capacitors, and radiation detectors 10,11. After disposal, it is finally deposited in the soil and is absorbed by plants and animals 10 . Figure 1 shows the environmental routes for human exposure to Cd.

Humans have increasingly been exposed to contaminants that pose risks to their quality of life and interfere in their health ${ }^{12}$. For example, cadmium is one of the most hazardous occupational and environmental poisons. Acute and chronic Cd exposure and accumulation in the body decreases the gastrointestinal absorption of calcium 13. The estimated half-life of $\mathrm{Cd}$ in the human body is 20 to 30 years 14 . A concentration of $200 \mu \mathrm{g} / \mathrm{g}$ can cause lesions in the proximal renal tubules, impairing the reabsorption of small protein molecules such as $\beta 2$-microglobulin $14,15,16$. Cd poisoning in so-called Itai-itati disease involves renal malfunctioning and bone deformities. Cd can also inhibit enzyme activity through binding with the sulfhydryl group (SH). It can react with organic compounds and thereby increase their toxicity 17 .

Biological indicators are fundamental tools in the assessment of health problems caused by exposure to chemical substances 18 . These indicators, associated with early and late biochemical and physiological alterations, provide information used to estimate the risk to human health 19 . By measuring these indicators, we can determine with relative accuracy the diseases resulting from these exposures 20,21. Biomarkers and human biomonitoring have thus emerged to develop practical methods for the direct measurement of biological and toxicological effects or responses to human exposure to xenobiotics 22 .

The data obtained from these studies were compared to reference values (RV) 23 . Subsequent analyses were processed specifically in comparison to the characteristics of the population from which they were derived and the physical environment around the study population, thus highlighting specificities of both manmade and natural target substances 22,23 . Such information provides backing for surveillance activities based on the substances found and the characteristics of the population exposed to them.

It is necessary to establish serum metal levels in an adult population in order to characterize the level of exposure to these substances and thus predict the real damage to human health in a given geographic location 23,24 . In this context, the current study aimed to investigate serum Cd levels in the adult population of Rio Branco, Acre State, Brazil, and associate them with occupational history, smoking, diet, and other economic and/or demographic variables that can interfere in and express Cd exposure.

\section{Methodology}

\section{Population and methods}

A cross-sectional study was performed to determine serum Cd levels in an adult population, obtaining prevalence rates for exposure to the metal with the respective confidence intervals in a sample according to sex and age group.

The sample was calculated considering the total of 6,000 blood donors registered with blood transfusion services in the State of Acre (DATASUS. http://www2.datasus.gov.br/ DATASUS/index.php, accessed 15/Sep/2013), as 
Environmental routes contributing to human exposure to cadmium.

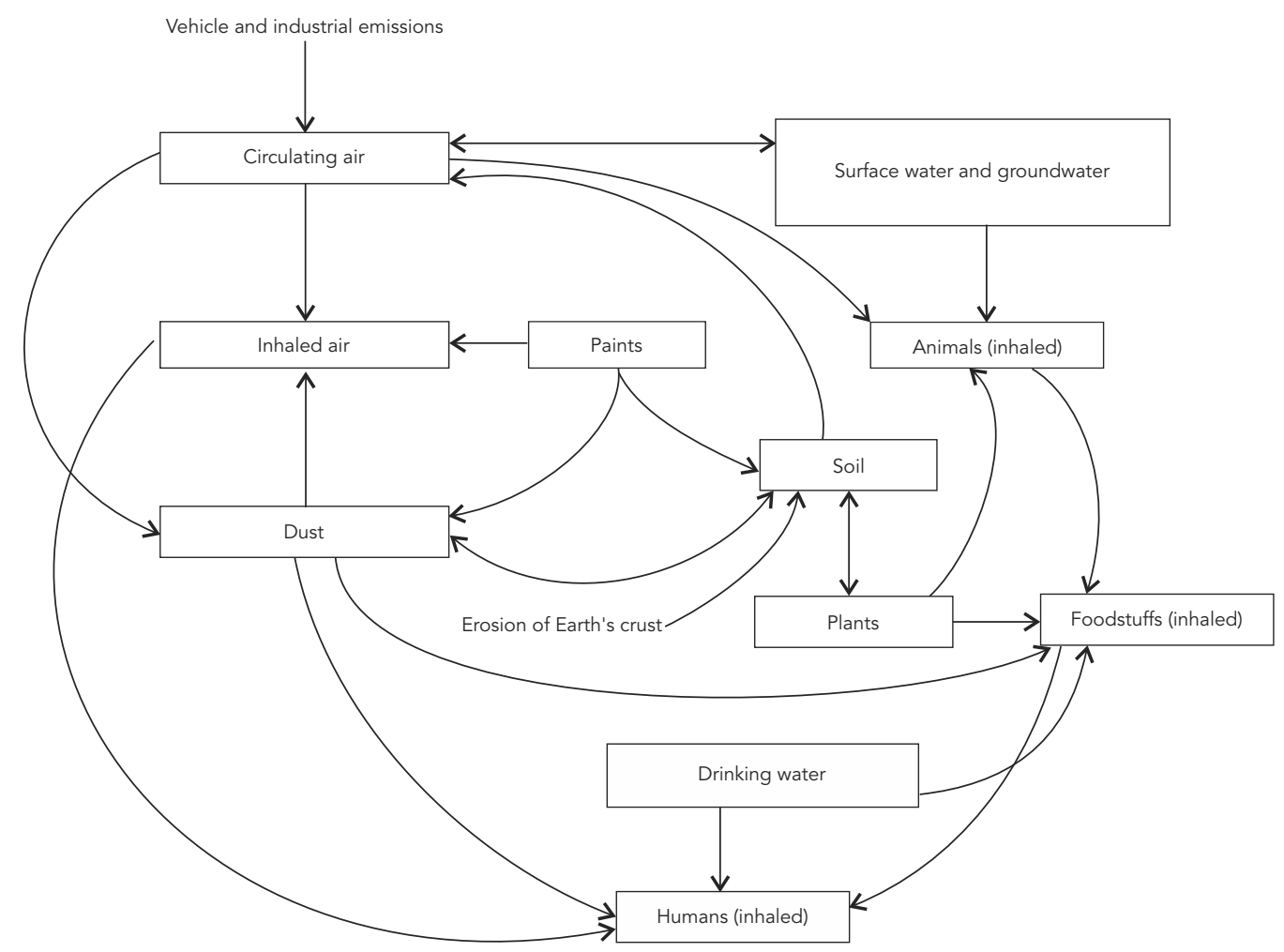

Note: modified from Azevedo \& Chasin 34

well as a $50 \%$ maximum population prevalence rate for Cd exposure. Assuming a $46 \%$ prevalence rate (if the previous estimate was the true population parameter) and setting reliability at $99 \%$, the study sample was estimated as at least 884 participants in order to determine the prevalence rates for Cd exposure.

Thus, a total of 1,193 blood donors consented to participate in the study and were interviewed. Data collection procedures were conducted in the Hemoacre blood donation center in Rio Branco, with donors of both sexes ranging from 18 to 65 years of age (the age bracket for recruiting donors in blood centers in Brazil). Participants were selected among healthy volunteer blood donors (through clinical and laboratory screening in the blood centers according to standardized criteria by the Brazilian National Health Surveillance Agency - ANVISA). These criteria met with Joint Technical Note n. 001 of 2010, issued by ANVISA 25 . Of the blood samples, 271 presented serum Cd levels below the limits of detection. The final study population thus consisted of 922 donors. Selection of volunteers, application of the data collection instrument, and drawing of blood samples took place from August 2010 to February 2011.

\section{Procedures for drawing and storing blood samples}

Blood samples were drawn from a vein of the upper limb using Vacutainer type equipment (Becton Dickinson BD, Curitiba, Brazil) in a $5 \mathrm{ml}$ tube containing EDTA (purple stopper), obtaining $5 \mathrm{ml}$ of blood per participant. The tubes were properly labeled, identified, and stored at $-18^{\circ} \mathrm{C}$. They were later transported by air to the Department 
of Clinical, Toxicological, and Bromatological Analyses at the School of Pharmaceutical Sciences, University of São Paulo in Ribeirão Preto (FCFRP-USP).

\section{Blood sample processing}

Serum Cd was measured according to the standard protocol of the FCFRP-USP Toxicology Laboratory. This is a robust and accessible analytical methodology, including multi-element capacity, in addition to obtaining lower limits of detection, thus making it one of the most appropriate techniques for biomonitoring and monitoring occupational exposures, since it provides much lower limits of detection and is simpler to interpret with minimum handling 26.

The blood samples were received at this laboratory, transferred to Eppendorf tubes (Labcon, São Paulo, Brazil) and stored in a freezer at $-18^{\circ} \mathrm{C}$. The tests were later performed with an inductively coupled plasma mass spectrometer (DRC-ICPMS ELAN DRCII, PerkinElmer, SCIEX, Norwalk, USA) operating with high purity argon (99.999\%, Praxaair, Brazil). The sample introduction system consisted of a quartz cyclone spray chamber and Meinhard nebulizer (Meinhard, Colorado, USA) connected by Tygon tubes (Saint-Gobain Corporation, Paris, France) with an ICP-MS peristaltic pump set to $20 \mathrm{rpm} 26$.

One reagent was deionized water with highgrade purity for preparing samples, and all the other reagents were analytical reagent grade, except the nitric acid $\left(\mathrm{HNO}_{3}\right)$, which was previously purified in a quartz sub-boiling system (Kürner Analysentechnik, Rosenheim, Germany) before use. The dilution water was previously purified with the Milli-Q system (Millipore, Bendford, USA).

A solution of $0.01 \%$ Triton X-100 (v/v) (SigmaAldrich, St. Louis, USA) $0.5 \% \mathrm{HNO}_{3}$ (v/v) served as the blood diluent. Solutions were prepared using a laminar flow hood. Blood samples for analysis were divided into aliquots and diluted at a proportion of 1:50 times.

The matrix adjustment calibration curve was prepared using sheep blood (animals not exposed to chemical substances). After venous puncture with a BD brand needle (Becton Dickinson BD, Curitiba, Brazil) (1.60mm x 40mm), the blood was drawn in several blue capped tubes, free of trace metals, containing $\mathrm{K}_{2}$ EDTA anticoagulant (BD Vacutainer). After drawing the sample, the tube was inverted eight times to ensure homogeneity and then frozen at $-18^{\circ} \mathrm{C}$. The analytical quality of the results was checked by analysis of reference materials in each series of samples. This baseline blood was screened to ensure that the endogenous levels of some elements were low, i.e., with sensitivity to identify cadmium as low as $<0.003 \mu \mathrm{g} / \mathrm{L} 26$. The results of the Cd levels according to DRC-ICP-MS are an average of three measurements of the material.

Application of questionnaire: history of exposure to chemical substances

To control for independent variables and possible confounders, donors answered a questionnaire at the time of the blood draw. Study variables included: schooling, leisure, income, diet, personal habits such as smoking, and use of teas, among others, to identify potential factors related to serum Cd levels, and which aided in the analysis and interpretation of the results.

A semi-structured questionnaire was prepared, including form and pertinence in relation to the objectives, with closed and open questions 27. All the interviews and blood collection were done from August 2010 to February 2011.

After appropriately coding the variables, a databank was prepared containing a dictionary with these codes and two additional spreadsheets with the first and second keying-in of the data. Validation consisted of a comparison of these two spreadsheets to check for inconsistences during feeding of the databank. The means of the triplicate serum Cd values were added to this databank, allowing cross-analysis of the information and appropriate statistical analyses.

\section{$\underline{\text { Study variables }}$}

The study's target variables were: socio-demographic (age, sex, marital status, schooling, family income, and profession); leisure-time activities (painting, pottery, and firearms practice); habits (such as smoking and consumption of teas); diet based on typical regional foods (fish, açaí, Brazil nuts, cassava flour, energy drinks); consumption of vitamins and diet supplements (as well as consumption of vitamins B and C) and vegetable garden at home and consumption of these vegetables; and factories or other industrial activities close to the home.

To record professions, all the answers were listed in order and later 6 groups were created based on the categories in the National Sample Household Survey (PNAD; http://www.ibge. gov.br/home/estatistica/populacao/trabalhoe rendimento/pnad2009, accessed 15/Feb/2012) in order to include the related activities, considering the similarity of possible risks. The categories were organized as follows: rural, health, operational, administrative, hotel industry, and other. 
Among the positive answers for tea consumption, a variable was created to check the consumption of teas made of Camellia sinensis (white tea, green tea, and black tea and the proper stratifications, such as mate, chimarrão, and tereré), in order to check the cadmium levels in the group of persons consuming them.

The dependent variable in the univariate analysis was mean serum cadmium level.

Although there is no reference value for serum Cd levels or official publications in Brazil indicating such values, the study chose to consider as the parameter for comparison not only the conservative values, but also intermediate levels published in various studies around the world. As presented previously, cadmium RVs vary from country to country, and we thus chose the value presented by Minoia et al. 28 for the population of the European Community, (Northern Italy), since the study design was similar (sample size, target age bracket, type of study). Thus, the mean cadmium values were later dichotomized between "less than or equal to the reference value" $(\leq 0.6 \mu \mathrm{g} / \mathrm{L})$ and "greater than the reference value" $(>0.6 \mu \mathrm{g} / \mathrm{L})$ based on the reference values adopted for the study's multivariate analysis $(\mathrm{Cd}-\mathrm{S}=$ $0.60 \pm 0.30 \mu \mathrm{g} / \mathrm{L}$ ).

\section{Data treatment and analysis}

The statistical analysis consisted initially of a univariate exploration in order to verify the distributions of each of the variables as measured, followed by a descriptive analysis. The study used SPSS, version 17.0 for Windows (SPSS Inc., Chicago, USA).

Serum Cd levels in the study population were characterized using absolute numbers (n) and relative frequencies (\%) with the respective confidence intervals in the different sample strata. The results will be shown as tables.

The measure of frequency of serum Cd levels was prevalence, with odds ratio as the measure of association. Pearson's chi-square test was used as the standard for veracity of relations. However, when the Pearson's test was not adequate, it was replaced by the Fisher's exact test. Odds ratios were obtained by forward logistic regression with 95\% significance.

\section{Ethical issues}

The study was approved by the Ethics Research Committee of the Federal University in Acre, case review number 23107.002611/2010-80, April 8, 2010.

\section{Results}

Age was stratified as follows: 18 to 29 years (48.4\%); 30 to 39 (32.8\%); 40 to 49 (14.3\%), and 50 to 65 (4.5\%). Of the latter, $74.9 \%$ were males.

Of the 1,193 samples, 271 presented serum Cd levels below limits of detection. All calculations were performed with $\mathrm{n}=922$.

Mean serum Cd was $0.37 \mu \mathrm{g} / \mathrm{L}$ (95\%CI: 0.330.41 ) and was higher among women, at $0.38 \mu \mathrm{g} / \mathrm{L}$ (95\%CI: 0.28-0.49). There was an increase in mean serum $\mathrm{Cd}$ with increasing age. Mean Cd was $0.31 \mu \mathrm{g} / \mathrm{L}$ (95\%CI: 0.26-0.36) among individuals below 30 years of age and $0.66 \mu \mathrm{g} / \mathrm{L}(95 \% \mathrm{CI}$ : 0.27-1.05) among those 50 years or older.

The opposite occurred with schooling, since mean Cd concentration varied inversely with years of schooling in the study population. Mean Cd was $0.61 \mu \mathrm{g} / \mathrm{L}$ (95\%CI: $0.34-0.89$ ) in individuals with less than five years of schooling and 0.34 $\mu$ /L (95\%CI: 0.28-0.40) among those with more than nine years. Individuals with monthly family income less than BRL500.00 showed high-

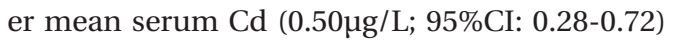
than the other income strata, below $0.40 \mu \mathrm{g} / \mathrm{L}$.

Mean serum Cd was three times higher in smokers than in non-smokers. Mean Cd in individuals that regularly drank teas was lower than in non-tea drinkers.

Among tea drinkers $(n=399)$, mean serum Cd was lower $(0.28 \mu \mathrm{g} / \mathrm{L})$ among those that drank teas made of $C$. sinensis (white tea, black tea, mate, green tea, chimarrão, and tereré) when compared to those who drank teas made of other plants $(0.34 \mu \mathrm{g} / \mathrm{L})$.

Table 1 shows mean serum cadmium levels in the various study strata, as well as confidence intervals and minimum and maximum cadmium levels.

As for distribution of socioeconomic, demographic, lifestyle, and dietary variables according to the RV adopted for serum Cd levels $(0.6 \mu \mathrm{g} / \mathrm{L})$, the frequency of individuals categorized above the RV was nearly double when compared to those equal to or below it in the 40 to 49 year age bracket. The trend was similar when analyzing individuals above 50 years of age, in which the relative frequency was three times higher in the category above the RV, with a p-value of $<0.001$.

Some variables showed lower relative frequencies in individuals categorized above the RV when compared to those equal to or below it, for example among those that consumed açaí, vitamins or supplements, and teas (but without statistical significance).

Although without statistical significance, the proportion of individuals above the RV was higher among those practicing leisure-time activities 
Mean ( $\mu \mathrm{g} / \mathrm{L})$, standard deviation, and confidence interval for serum cadmium levels according to socio-demographic variables and habits in a sample of blood donors. Rio Branco, Acre State, Brazil, 2010-2011.

\begin{tabular}{|c|c|c|c|c|c|c|c|c|}
\hline \multirow[t]{2}{*}{ Variables } & \multirow[t]{2}{*}{$\mathrm{n}$} & \multirow[t]{2}{*}{$\%$} & \multirow[t]{2}{*}{ Mean * } & \multirow[t]{2}{*}{ SD } & \multicolumn{2}{|c|}{$95 \% \mathrm{Cl}$} & \multirow[t]{2}{*}{ Minimum } & \multirow[t]{2}{*}{ Maximum } \\
\hline & & & & & LL & UL & & \\
\hline Total study population & 922 & 100.0 & 0.37 & 0.67 & 0.33 & 0.41 & 0.00 & 9.83 \\
\hline \multicolumn{9}{|l|}{ Sex } \\
\hline Male & 691 & 74.9 & 0.36 & 0.62 & 0.31 & 0.41 & 0.00 & 9.83 \\
\hline Female & 231 & 25.1 & 0.38 & 0.62 & 0.28 & 0.49 & 0.00 & 8.54 \\
\hline \multicolumn{9}{|l|}{ Age bracket (years) } \\
\hline$<30$ & 445 & 48.4 & 0.31 & 0.52 & 0.26 & 0.36 & 0.00 & 8.54 \\
\hline $30-39$ & 302 & 32.8 & 0.39 & 0.84 & 0.30 & 0.49 & 0.00 & 9.83 \\
\hline $40-49$ & 132 & 14.3 & 0.40 & 0.37 & 0.34 & 0.47 & 0.01 & 2.30 \\
\hline$\geq 50$ & 41 & 4.5 & 0.66 & 1.22 & 0.27 & 1.05 & 0.01 & 7.88 \\
\hline \multicolumn{9}{|l|}{ Marital status } \\
\hline Single & 378 & 41.6 & 0.34 & 0.72 & 0.27 & 0.42 & 0.00 & 9.83 \\
\hline Married, stable union & 504 & 55.5 & 0.38 & 0.64 & 0.33 & 0.44 & 0.00 & 9.04 \\
\hline Widow(er) & 3 & 0.3 & 0.20 & 0.12 & 0.09 & 0.49 & 0.08 & 0.12 \\
\hline Divorced & 23 & 2.5 & 0.40 & 0.76 & 0.07 & 0.73 & 0.01 & 3.76 \\
\hline \multicolumn{9}{|l|}{ Schooling (years) } \\
\hline$\leq 4$ & 59 & 6.6 & 0.61 & 1.06 & 0.34 & 0.89 & 0.01 & 7.88 \\
\hline $5-8$ & 115 & 12.8 & 0.40 & 0.51 & 0.30 & 0.50 & 0.02 & 4.50 \\
\hline $9-11$ & 430 & 48.0 & 0.34 & 0.60 & 0.28 & 0.40 & 0.00 & 9.83 \\
\hline$>12$ & 291 & 32.5 & 0.34 & 0.76 & 0.26 & 0.43 & 0.00 & 9.04 \\
\hline \multicolumn{9}{|l|}{ Family income (BRL) } \\
\hline$\leq 500$ & 40 & 4.6 & 0.50 & 0.69 & 0.28 & 0.72 & 0.01 & 3.76 \\
\hline $500-1,000$ & 190 & 21.8 & 0.40 & 0.64 & 0.30 & 0.49 & 0.00 & 7.88 \\
\hline $1,001-1,500$ & 220 & 25.3 & 0.34 & 0.32 & 0.30 & 0.38 & 0.00 & 2.07 \\
\hline $1,501-3,000$ & 263 & 30.2 & 0.34 & 0.65 & 0.26 & 0.41 & 0.01 & 9.04 \\
\hline$>3,000$ & 157 & 18.0 & 0.34 & 0.78 & 0.22 & 0.46 & 0.01 & 8.54 \\
\hline \multicolumn{9}{|l|}{ Profession } \\
\hline Rural & 25 & 3.1 & 0.30 & 0.22 & 0.20 & 0.39 & 0.02 & 0.81 \\
\hline Health & 43 & 5.3 & 0.35 & 0.38 & 0.23 & 0.46 & 0.01 & 1.91 \\
\hline Operational & 221 & 27.1 & 0.31 & 0.64 & 0.23 & 0.40 & 0.00 & 8.54 \\
\hline Administrative & 424 & 52.0 & 0.36 & 0.53 & 0.31 & 0.41 & 0.00 & 9.04 \\
\hline Hotel industry & 41 & 5.0 & 0.52 & 1.51 & 0.04 & 1.00 & 0.01 & 9.83 \\
\hline Other & 61 & 7.5 & 0.30 & 0.25 & 0.24 & 0.37 & 0.01 & 1.39 \\
\hline \multicolumn{9}{|l|}{ Smoker } \\
\hline No & 818 & 89.1 & 0.30 & 0.50 & 0.26 & 0.33 & 0.00 & 9.04 \\
\hline Yes & 100 & 10.9 & 0.92 & 1.35 & 0.65 & 1.19 & 0.01 & 9.83 \\
\hline \multicolumn{9}{|l|}{ Tea consumption } \\
\hline No & 523 & 56.7 & 0.41 & 0.86 & 0.29 & 0.24 & 0.00 & 9.83 \\
\hline Yes & 399 & 43.3 & 0.31 & 0.29 & 0.28 & 0.34 & 0.00 & 2.30 \\
\hline
\end{tabular}

SD: standard deviation; 95\% Cl: 95\% confidence interval; LL: lower limit; UL: upper limit.

* Mean serum cadmium levels for each stratum $(\mu \mathrm{g} / \mathrm{L})$.

classified as involving exposure, those that consumed fish or cassava flour, those with vegetable gardens at home, and those living near factories or other industrial activities.
As for factors associated with serum cadmium levels above the reference value, adjusted by logistic regression, the analysis pointed to an association with the variables age, marital status, 
schooling, leisure-time activities, and having a vegetable garden. Thus, the odds of presenting serum Cd above the RV showed an upward trend with increasing age, with $\mathrm{OR}=1.35$ (95\%CI: 0.822.22 ) among individuals 30 to 39 years of age, $\mathrm{OR}=2.65$ (95\%CI: 1.53-4.61) for 40 to 49 years, and $\mathrm{OR}=5.89(95 \% \mathrm{CI}: 2.84-12.22)$ for greater than 50 years.

The odds of serum CD above the RV were lower among those with more schooling. Among individuals with 9 to 11 years of schooling, the odds were 3.8 greater than among those with more than 12 years. And the odds were 1.5 times greater for those with 5 to 8 years and 1.3 times greater for those with up to 4 years, when compared to those with more than 12 years of schooling.

Smoking showed a positive association, with OR $=12.36$ (95\%CI: 7.70-19.84) for serum Cd levels above the RV in smokers compared to nonsmokers.

Although without statistical significance, the analysis pointed to a positive association between serum Cd levels above the RV for the following variables: non-single marital status $(\mathrm{OR}=1.43$; 95\%CI: 0.93-2.18); leisure-time activities with exposure (OR $=1.46$; 95\%CI: 0.962.22); and having a vegetable garden at home $(\mathrm{OR}=1.55$; 95\%CI: 0.97-2.47). Importantly, even after adjusting with logistic regression, "age" and "smoking" continued to show a positive and statistically significant association.

Figure 2 shows the study population's distribution according to serum Cd levels and RV, with $11.7 \%$ of the study population above the RV (cutoff: $\mathrm{Cd}-\mathrm{S}>0.6 \mu \mathrm{g} / \mathrm{L}$ ).

Figure 3 shows the study population's distribution by serum Cd, broken down by smoking. Among smokers $(\mathrm{n}=100), 49 \%$ showed serum Cd levels above the RV, while among non-smokers ( $n=818$ ) only $7.2 \%$ showed serum Cd above the RV.

\section{Discussion}

Since cadmium is not an essential metal, the mere presence of this analyte in the individuals studied here means the existence of exposure. Serum Cd levels were mostly below the reference value (88.3\% of participants). Mean Cd levels in the current study indicate that in general the study population is not exposed to worrisome CD levels. In addition, Cd level was significantly associated with age bracket. Serum Cd levels above the RV increased with age, smoking, and dietary and environmental sources of exposure.

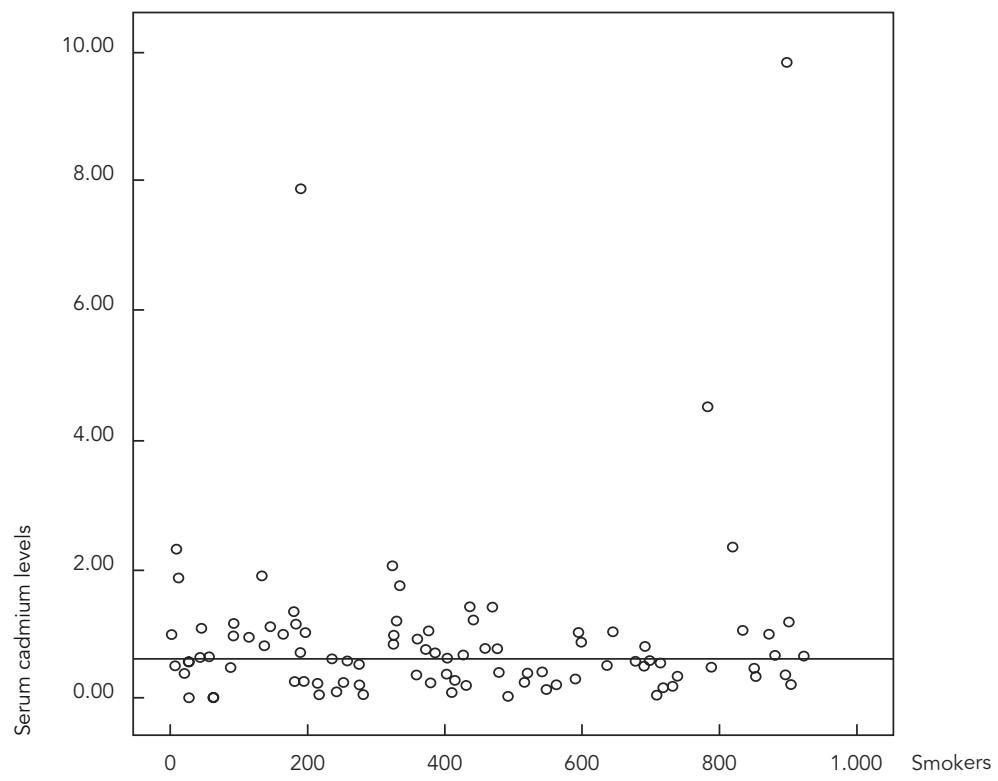


Distribution of study population according to serum cadmium levels, disaggregated by smoking status, compared to reference value (Cd-S = 0.6 $\mathrm{g} / \mathrm{L})$. Rio Branco, Acre State, Brazil, 2010-2011.

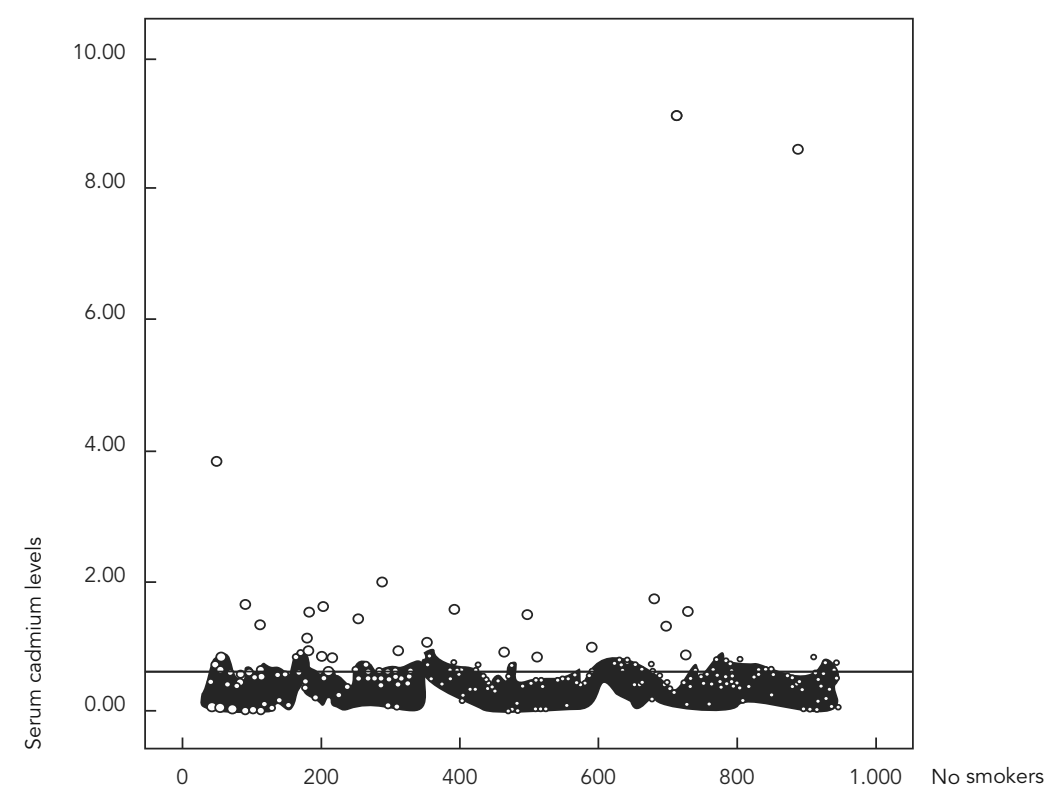

According to a field survey in July 2011 to measure cadmium in environmental samples (water and soil) from 10 sites in the metropolitan area of Rio Branco, the levels were either undetectable or negligible, leading us to rule out the environment as a source of exposure. The levels suggest that cadmium exposure is non-environmental in Rio Branco. Table 2 shows the results of this survey.

Our results corroborate important exposure to Cd from foods. In Spain, for example, the most frequent source of oral exposure to cadmium is contaminated water 29 . Other authors conclude that the consumption of fish (previously known for Cd contamination) among fisherman in Sepetiba Bay (Rio de Janeiro) shows a 110-fold risk of contamination 27 .

This study focused on consumption of typical foods for the Rio Branco region, such as cassava flour and açai. Despite high consumption of these foods, Cd levels were not statistically significant between the groups.

One factor that is widely observed and discussed in studies is Cd exposure from smoking. Several studies have shown elevated Cd levels in smokers 30,31 . Smoking is one of the main sources of Cd exposure, doubling its absorption, due to accumulation of the metal in the soil and thus in tobacco leaves. A single cigarette can contain $1-2 \mu \mathrm{g}$ of Cd, which can enter the human body through inhalation and absorption by the lungs 8 .

Studies are unanimous in reporting serum Cd levels 2 to 3 times higher in smokers when compared to non-smokers or former smokers 32,33. In the Czech Republic, Batariová et al. 33 found serum Cd levels of $1.3 \mu \mathrm{g} / \mathrm{L}$ and $0.4 \mu \mathrm{g} / \mathrm{L}$ among smokers and non-smokers, respectively. The current study thus corroborated Brazilian and in ternational studies (three-fold higher Cd levels in smokers), thereby confirming smoking as one of the principal risk factors for increased serum cadmium.

The biological material used for analysis here provides information on recent exposure and is an excellent parameter for assessing work activities or technological controls. However, understanding exposure to this metal would benefit from testing urine as the biological material. Importantly, the lack of reference values published by official Brazilian agencies for serum $\mathrm{Cd}$ levels limits the comparison between this study and others and its extrapolation to the general population. 
Mean values (in ppb) and standard deviation (SD) for cadmium level in environmental samples (soil and water) in Rio Branco, Acre State, Brazil, 2010-2011.

\begin{tabular}{lcccc}
\hline Collection site & Soil (ppb) & & & Water (ppb) \\
& Value & SD & Value & SD \\
\hline Site 1 & 101.48 & 3.723 & 0.12 & 0.009 \\
Site 2 & 12.76 & 0.328 & 0.11 & 0.008 \\
Site 3 & 67.12 & 1.465 & 0.19 & 0.017 \\
Site 4 & 129.28 & 1.833 & 0.12 & 0.019 \\
Site 5 & 32.54 & 0.285 & 0.12 & 0.011 \\
Site 6 & 41.54 & 1.514 & 0.10 & 0.022 \\
Site 7 & - & - & 0.12 & 0.012 \\
Site 8 & 30.75 & 0.709 & 0.22 & 0.004 \\
Site 9 & 46.97 & 0.827 & 3.10 & 0.018 \\
Site 10A & 44.86 & 2.917 & 0.14 & 0.009 \\
Site 10B & 4.83 & 0.088 & 0.09 & - \\
Site 10C & 11.20 & 0.533 & - & 0.39 \\
Site 10D & - & - & 0 & 0 \\
\hline
\end{tabular}

Site 1: Stabilization pond, University Complex. S 09 $56^{\prime} 41.9^{\prime \prime} \mathrm{W} 67^{\circ} 52^{\prime} 24.3^{\prime \prime}$. Soil and water samples (T: $\left.21^{\circ} \mathrm{C} ; \mathrm{pH}: 5.0\right)$.

Site 2: Plastics factory. S 0956'51.1" W 67052'01.4". Soil and water samples (T: $\left.25^{\circ} \mathrm{C} ; \mathrm{pH}: 5.0\right)$;

Site 3: Bathing area. S $10^{\circ} 00^{\prime} 12.4^{\prime \prime} \mathrm{W} 67^{\circ} 51^{\prime} 03.5^{\prime \prime}$. Soil and water samples. (T: $\left.22^{\circ} \mathrm{C} ; \mathrm{pH}: 5.0\right)$;

Site 4: Former garbage dump. S 1000'53.7" W 67]54'40.2". Soil and water samples (T: $\left.20^{\circ} \mathrm{C} ; \mathrm{pH}: 5.0\right)$;

Site 5: Water catchment station. S 1000'36.2" W 67050'37.5". Soil and water samples (T: 21]C; pH: 6.0);

Site 6: Motor vehicle body factory. S $10^{\circ} 00^{\prime} 47.4^{\prime \prime} \mathrm{W} 67^{\circ} 46^{\prime} 12.5^{\prime \prime}$. Soil and water samples (T: $\left.20^{\circ} \mathrm{C} ; \mathrm{pH}: 5.0\right)$;

Site 7: Jewelry factory. S 09 $58^{\prime} 40.3^{\prime \prime} \mathrm{W} 67^{\circ} 48^{\prime} 38.2^{\prime \prime}$. Water samples (T: $22^{\circ} \mathrm{C} ; \mathrm{pH}: 4.0$ );

Site 8: Thermoelectric plant. S $09^{\circ} 57^{\prime} 55.4^{\prime \prime} \mathrm{W} 67^{\circ} 47^{\prime} 30.7^{\prime \prime}$. Soil and water samples (T: $26^{\circ} \mathrm{C} ; \mathrm{pH}: 5.0$ );

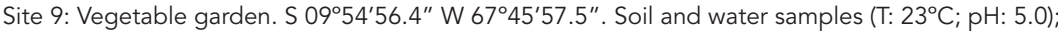

Site 10: Solid waste treatment unit. S $10^{\circ} 02^{\prime} 10.3^{\prime \prime}$ W 67 $37^{\prime} 020^{\prime \prime}$. Three soil samples, 2 water samples, and 1 leachate sample. This site 10 was divided into 4 collection sub-sites, thus recorded: 10A (lagoon before dumping leachate), 10B (lagoon after dumping leachate), 10C (solid landfill), and 10D (leachate, before being dumped into the lagoon). At site 10A, soil and water samples (T: $\left.23^{\circ} \mathrm{C} ; \mathrm{pH}: 5.0\right)$; site $10 \mathrm{~B}$, soil and water samples ( $\left.\mathrm{T}: 22^{\circ} \mathrm{C} ; \mathrm{pH}: 5.0\right)$; site $10 \mathrm{C}$, only soil samples; site $10 \mathrm{D}$, leachate sample $\left(\mathrm{T}: 21^{\circ} \mathrm{C} ; \mathrm{pH}: 8.0\right)$.

\section{Conclusion}

Considering that cadmium is not an essential chemical element, its presence in the blood of individuals in this sample indicates exposure, even at low levels. According to the results, 99.6\% of the population showed quantifiable Cd levels in the blood.

Serum Cd levels were slightly higher in women, although the difference was not statistically significant. Individuals over 50 years of age also showed an increase in serum Cd. Individuals with less schooling showed higher serum Cd levels. The same was true for income, where serum Cd tended to increase as income decreased.

The study highlighted the variables with the strongest positive association with serum $\mathrm{Cd}$ levels, namely age bracket and smoking. The $\mathrm{Cd}$ values presented here thus suggest that exposure is related to the environment in which people live and their habits, even with levels within what are considered acceptable limits for the general population.

The current system for monitoring and prevention is sufficiently efficient to anticipate all the possible risks for the population. Thus, the inclusion of routine serum Cd testing could provide important data for planning and public policies, resulting in improved health conditions for the population.

Finally, this study opens significant and wellbased prospects to debate, suggest, and develop targets for protecting human health, since it allows addressing important pending issues in environmental control, such as establishing maximum limits and tolerable risk for cadmium, 
creation and revision of standards, and implementation of public policies to promote public health.

A new development model is needed that harmonizes improvement of quality of life for the populations, environmental preservation, and the search for creative solutions to meet citizens' demands for access to health. These issues point to an in-depth reflection on the need to implement health promotion programs that result in better quality of life.

\section{Resumen}

El objetivo de utilizar un estudio transversal para determinar la distribución de los niveles séricos de Cd en los donantes de Río Branco no expuestos al metal. Se obtuvo sangre de 922 voluntarios de entre 18 y 65 años en Hemoacre entre 2010-2011. La concentración media de Cd fue 0,37 $\mu \mathrm{g} / \mathrm{L}$ (IC95\%: 0,33-0,41). Hubo una tendencia de aumento según el nivel educativo: las personas con menos de cinco años de estudio tenían una media de 0,61 $\mathrm{g} / \mathrm{l}$ (IC95\%: 0,34-0,89), mientras que quienes contaban con más de nueve años de escolaridad poseían un promedio 0,34 $\mu \mathrm{g} / \mathrm{L}$ (IC95\%: 0,28-0,40). La concentración promedio de Cd se presentó tres veces mayor entre los fumadores. El consumo de cigarrillos mostró una asociación positiva con OR 12,36 (IC95\%: 7,70-19,84). Ya la concentración de Cd en las personas con hábitos de tomar té era más pequeña en comparación con aquellos que no lo toman. Los niveles séricos de Cd fueron en su mayoría por debajo del valor de referencia (88,3\% de los participantes). Los medios encontrados en este estudio indican que, en general, la población no está expuesta a niveles preocupantes de Cd.

Cadmio; Donantes de Sangre; Estudios Transversales

\section{Contributors}

A. R. M. C. Faro participated in the conception, data collection, processing, analysis, and interpretation, literature review, and writing of the article. W. J. Pinto oriented the study and contributed to the final draft. A. P. Ferreira oriented the study and contributed to the final draft. F. Barbosa Júnior analyzed and interpreted the data. V. C. O. Souza, D. E. Fujimoto, and R. J. Koifman conducted a relevant critical revision of the article's intellectual content. S. Koifman was responsible for the conception, study project, and writing the article.

\section{Acknowledgments}

The research project was made possible by academic collaboration between the Graduate Studies Program in Collective Health at the Federal University in Acre and the Graduate Studies Program in Public Health and Environment at the Sergio Arouca National School of Public Health, Oswaldo Cruz Foundation, which has received funding from the National Council for Scientific and Technological Development (CNPq: Call for Collaborative Projects UFAC-Fiocruz, case n. 620024/2008-9 and Capes/ PROCAD-NF 1442/2007 and PROCAD-NF 2557/2008 Programs). 


\section{References}

1. Bernard A, Lauwerys R. Assessment of human exposure to chemicals through biological monitoring. In: Kopfler FC, Craun GF, editors. Environmental epidemiology. Chelsea: Lewis Publishers; 1986. p. 17-28.

2. World Health Organization. Biological monitoring of chemical exposure in the workplace. Geneva: World Health Organization; 1996.

3. Dougherty J. Employee health monitoring data bases and their role in defining the safety of chemical products. Int Arch Occup Environ Health 1998; 71:101-3.

4. Kah M, Levy L, Brown C. Potential for effects of land contamination on human health. 1 . The case of cadmium. J Toxicol Environ Health B Crit Rev 2012; 15:348-63.

5. Eisler R. Handbook of chemical risk assessment: health hazards to humans, plants, and animals. Boca Raton: Lewis Publishers; 2000.

6. Ferreira AP, Horta MAP, Cunha CLN. Avaliação das concentrações de metais pesados no sedimento, na água e nos órgãos de Nyctiocorax nyctiocorax et 'garça-da-noite' na Baía de Sepetiba, RJ. Journal of Integrated Coastal Zone Management 2010; 10: 81-93.

7. Nogueira CA, Margarido F. Nickel-cadmium batteries: effect of electrode phase composition on acid leaching process. Environ Technol 2012; 33:359-66

8. Govil PK, Sorlie JE, Murthy NN, Sujatha D, Reddy GL, Rudolph-Lund K, et al. Soil contamination of heavy metals in the Katedan Industrial Development Area, Hyderabad, India. Environ Monit Assess 2008; 140:313-23.

9. Eriksson E, Revitt DM, Ledin A, Lundy L, Holten Lützhøft HC, Wickman T, et al. Water management in cities of the future using emission control strategies for priority hazardous substances. Water Sci Technol 2011; 64:2109-18.

10. Järup L. Hazards of heavy metal contamination. $\mathrm{Br}$ Med Bull 2003; 68:167-82.

11. Järup L, Akesson A. Current status of cadmium as an environmental health problem. Toxicol Appl Pharmacol 2009; 238:201-8.

12. Allan SE, Sower GJ, Anderson KA. Estimating risk at a superfund site using passive sampling devices as biological surrogates in human health risk models. Chemosphere 2011; 85:920-7.

13. Hasan MY, Kosanovic M, Fahim MA, Adem A, Petroianu G. Trace metal profiles in hair samples from children in urban and rural regions of the United Arab Emirates. Vet Hum Toxicol 2004; 46:119-21

14. Hwangbo Y, Weaver VM, Tellez-Plaza M, Guallar E, Lee BK, Navas-Acien A. Blood cadmium and estimated glomerular filtration rate in Korean adults. Environ Health Perspect 2011; 119:1800-5.

15. Suwazono Y, Uetani M, Akesson A, Vahter M. Recent applications of benchmark dose method for estimation of reference cadmium exposure for renal effects in man. Toxicol Lett 2010; 198:40-3.
16. Limpatanachote P, Swaddiwudhipong W, Mahasakpan P, Krintratun S. Cadmium-exposed population in Mae Sot District, Tak Province: 2. Prevalence of renal dysfunction in the adults. J Med Assoc Thai 2009; 92:1345-53.

17. Zhou Q, Zhang J, Fu J, Shi J, Jiang G. Biomonitoring: an appealing tool for assessment of metal pollution in the aquatic ecosystem. Anal Chim Acta 2008; 606:135-50.

18. Matejczyk M, Płaza GA, Nałęcz-Jawecki G, Ulfig K, Markowska-Szczupak A. Estimation of the environmental risk posed by landfills using chemical, microbiological and ecotoxicological testing of leachates. Chemosphere 2011; 82:1017-23.

19. Roselló MJP, Martinez JMV, Navarro AB. Vulnerability of human environment to risk: case of groundwater contamination risk. Environ Int 2009; 35:325-35.

20. Li J, Lu Y, Shi Y, Wang T, Wang G, Luo W, et al. Environmental pollution by persistent toxic substances and health risk in an industrial area of China. J Environ Sci 2011; 23:1359-67.

21. Birkmann J. Risk and vulnerability indicators at different scales: applicability, usefulness and policy implications. Environmental Hazards 2007; 7:20-31.

22. Apostoli P, Baj A, Bavazzano P, Ganzi A, Neri G, Ronchi A, et al. Blood lead reference values: the results of an Italian polycentric study. Sci Total Environ 2002; 287:1-11.

23. Owen R, Galloway TS, Hagger JA, Jones MB, Depledge $\mathrm{MH}$. Biomarkers and environmental risk assessment: guiding principles from the human health field. Mar Poll Bull 2008; 56:613-9.

24. Amorim LCA. Os biomarcadores e sua aplicação na avaliação da exposição aos agentes químicos ambientais. Rev Bras Epidemiol 2003; 6:1-13.

25. Agência Nacional de Vigilância Sanitária. Nota técnica conjunta no 001/2010/GGSTO/ANVISA. http://portal.anvisa.gov.br/wps/portal/anvisa/ home/sanguetecidoorgaos/!ut/p/c4/04_SB 8K8xLLM9MSSzPy8xBz9CP0os3hnd0cPE3M fAwN3f1dLA0 IEvLUE9DYwMDc_2CbEdFAPf3 0UY!/?WCM_PORTLET=PC_7_CGAH47L00GOE 90IOR99UI130C1_WCM\&WCM_GLOBAL_CON $\mathrm{TEXT}=/ \mathrm{wps} / \mathrm{wcm} / \mathrm{connect/anvisa/anvisa/inicio/}$ sangue+tecidos+e+orgaos/publicacao+sangue+te cidos+e+orgaos/nota+tecnica+conjunta $+\mathrm{n}+001+2$ 010+ggsto+anvisa (accessed on 07/Mar/2011).

26. Batista BL, Rodrigues JL, Nunes JA, Souza VCO, Barbosa Jr. F. Exploiting dynamic reaction cell inductively coupled plasma mass spectrometry (DRC-ICP-MS) for sequential determination of trace elements in blood using a dilute-and-shoot procedure. Anal Chim Acta 2009; 639:13-8.

27. Gil AC. Métodos e técnicas de pesquisa social. $5 \underline{a}$ Ed. São Paulo: Editora Atlas; 1999. 
28. Minoia C, Sabbioni E, Apostoli P, Pietra R, Pozzoli L, Gallorini M, et al. Trace element reference values in tissues from inhabitants of the European Community. I. A study of 46 elements in urine, blood and serum of Italian subjects. Sci Total Environ 1990; 95:89-105.

29. Horta MAP, Ferreira AP, Luzardo AJR, Brignol V, Faro ARMC, Pinto WJ. Risk analysis of cadmium intake by fish consumers in a sub-tropical coastal lagoon, Sepetiba Bay-SE, Brazil. Rev Bras Promoç Saúde 2011; 24:46-53.

30. Satarug S, Moore MR. Adverse health effects of chronic exposure to low-level cadmium in foodstuffs and cigarette smoke. Environ Health Perspect 2004; 112:1099-103.

31. Satarug S, Garrett SH, Sens MA, Sens DA. Cadmium, environmental exposure, and health outcomes. Environ Health Perspect 2011; 16: 2587-602.
32. González-Estecha M, Trasobares E, Fuentes M, Martínez MJ, Cano S, Vergara N, et al. Blood lead and cadmium levels in a six hospital employee population. PESA study, 2009. J Trace Elem Med Biol 2011; 255:S22-9.

33. Batáriová A, Spevácková V, Benes B, Cejchanova $\mathrm{M}$, Smid J, Cerná M. Blood and urine levels of $\mathrm{Pb}$, $\mathrm{Cd}$ and $\mathrm{Hg}$ in the general population of the Czech Republic and proposed reference values. Int J Hyg Environ Health 2006; 209:359-66.

34. Azevedo FA, Chasin AMM. As bases toxicológicas de ecotoxicologia. São Paulo: InterTox; 2003.

Submitted on 17/Apr/2013

Final version resubmitted on 24/Jun/2013

Approved on 12/Jul/2013 